\title{
Prediction of rabbit meat and bone weight using carcass measurements and sample cuts
}

\author{
A. BLASCO, I. ESTANY and M. BASELGA \\ Cátedra de Fisiogenética, ETSIA. Universidad Politécnica. \\ Valencia 22 España
}

\begin{abstract}
Summary
Regression equations predicting dissectable muscle weight in rabbits from external carcass measurements were presented. Bone weight and weight of muscle groups were also predicted.

Predictive capacity of external measurements, retail cuts and muscle groups on total muscle, percent muscle, total bone and muscle to bone ratio were studied separately.

Measurements on dissected retail cuts should be included in order to obtain good equations for prediction of percent muscle in the carcass.

Equations for predicting the muscle to bone ratio using external measurements and data from the dissection of one hind leg were suggested.

The equations had generally high coefficients of determination. The coefficient of determination for prediction of dissectable muscle was 0.91 , and for percent muscle in the carcass 0.79 .
\end{abstract}

Key words : rabbit, meat, carcass, bone, muscle, correlations.

\section{Introduction}

Meat rabbit production has developed recently and only few studies are available about the prediction of carcass composition. Rouvier (1970), CANTIER et al., (1974), JaniszewSKa \& Bochno (1979), Bochno et al., (1979), VAREWyck \& Bouquet (1982). Only JANISZEWSKA \& Bochno (1979) and Bochno et al. (1979) made equations for predicting carcass composition from external measurements. No work has been devoted to the measurement of percent of muscle in the carcass. Therefore, it seemed to be interesting to find unsophisticated and inexpensive measurements for estimating the edible meat and its percentage in the carcass for application in genetic improvement programme or simply in economic carcass evaluation.

The purpose of this study was the following :

1) Find equations that relate carcass measurements with muscle and bone weight, muscle to carcass weight and muscle to bone ratio.

2) Determine the predictive capacity of retail cuts, individual muscle weight and muscle weight on weight and percentage of muscle in the carcass. 


\section{Material and Methods}

\section{A. Animals}

A total of 103 carcasses from a Californian line described by BASELGA (1978) were dissected. All the rabbits were 77-day old at slaughter. No division between sexes was considered as sexual dimorphism does not arise at that age yet CANTIER et al. (1969). Dissections were made 24 to $48 \mathrm{~h}$, after slaughter.

\section{B. Variables measured}

Before dissection the following variables were measured :

SW : slaughter weight

$\mathrm{CW}$ : carcass weight $24 \mathrm{~h}$ after slaughter, including internal fat depots, internal organs (liver, kidneys, heart, lungs, thymus) and head, according to the Spanish carcass

$\mathrm{L} \quad$ : length between the neural spines of atlas and last sacral vertebra

LL : length between the neural spines of first and last lumbar vertebra (loin length)

HLL : length from the neural spines of last lumbar vertebra to the insertion of the calcaneus comunis tendon (hind leg length)

SL : length from wing-like portion of ilium to ischial tuberosity (sacral length)

HLW : length from the neural spine of the last-lumbar vertebra to ischial tuberosity (hind leg width)

W : width between the 3rd tracanters of both femurs

C : circumference at the level of the 7 th lumbar vertebra, including abdominal walls

Head at the level of axis $(\mathrm{H})$, liver (LI), kidneys (KI), heart, lungs and thymus as a whole $(\mathrm{H}+\mathrm{L})$ and internal fat depots were separated from the carcass. Then it was divided into the following retail cuts :

FL : fore legs including the muscles of insertion in the body

HL : hind legs including sacral bone

LO : loin including sacral and caudal vertebrae and abdominal walls

BR : breast and ribs

Each one of these cuts was dissected and the individual groups of muscles considered were :

MHL : muscle of the hind leg

MFL : muscle of the fore leg

$\mathrm{P}_{1}$ : Psoas major 
$\mathrm{P}_{2} \quad$ : Psoas minor

MBR : muscles of breast and ribs excluding the thoracic fraction of Longissimus muscle

AW : Abdominal walls

TLM : Thoracic Longissimus muscle

LLM : Lumbar Longissimus muscle

LM : Total Longissimus muscle

MT : Total dissected muscle

In MHL and MFL only one leg, chosen at random, was dissected.

Muscle contained among ribs and vertebrae was not separated, as it was ascertained that losses were less than 2 p. 100 with respect to total muscle in the carcass.

Bone of fore leg $(B F L)$, bone of hind leg $(B H L)$, and the rest of the bones separated in the dissection (BB) were also weighted.

From previous variables measured directly the following variables were formed:

$\mathbf{M}=\mathrm{MHL}+\mathrm{MFL}+\mathrm{MT}$. Total muscle of the carcass

$\mathrm{B}=\mathrm{BFL}+\mathrm{BHC}+\mathrm{BB}$. Total bone of the carcass

LOM $=\mathrm{LML}+\mathrm{AW}+\mathrm{P}_{1}+\mathrm{P}_{2}$. Loin muscle as a whole

$\mathrm{BRM}=\mathrm{MBK}+\mathrm{TML}$. Breast and rib muscles as a whole

$\mathrm{LR}=\mathrm{MHL} / \mathrm{BHL}$. Leg ratio

Percent of muscle in the carcass $(\mathrm{M} / \mathrm{CW})$, meat/bone ratio $(\mathrm{M} / \mathrm{B})$, and 2 measures of compactness $(\mathrm{W} / \mathrm{L}$ and $\mathrm{C} / \mathrm{L}$ ) were also used.

\section{Statistical analyses}

The prediction ability of each variable was evaluated by simple regression on $\mathrm{M}, \mathrm{B}, \mathrm{M} / \mathrm{CW}$, and $\mathrm{M} / \mathrm{B}$. Within each case the coefficient of determination $\mathrm{R}^{2}$ was examinated $\left(\mathrm{R}_{\mathrm{M}}^{2}, \mathrm{R}^{2}, \mathrm{R}_{\mathrm{M} / \mathrm{CW}}^{2}, \mathrm{R}_{\mathrm{M} / \mathrm{3}}^{2}\right.$ respectively).

Stepwise regression analysis on $\mathrm{M}, \mathrm{B}, \mathrm{LOM}, \mathrm{BRM}$ and MHL, MFL, LM muscle groups were made. Stepwise regression procedure consists essentially (DrApper \& SMITH, 1981) in entering or removing the variables from the equation one at a time until the regression equation is satisfactory enough. The process stops when a new variable does not supply sufficient amount of new information. Thus, a satisfactory regression equation with the less possible number of variables may be obtained. The first variable selected is that being the most correlated with the dependent variable (Y). If this variable overcomes the F-entry test (that is, if it is significant) a first equation is fitted. Additionally, the next variable to introduce in to the equation will be that whose partial correlation with the dependent variable was the greatest of the remaining variables. The same procedure is repeated taking into account the variables not included in the present equation.

At each stage, partial F-values for all variables in the equation are examined. The lower of these partial F's is compared with a prechosen percentage point of 
the appropriate $\mathrm{F}$ distribution ( $5 \mathrm{p} .100$ is usual). If the tested variable provides a non significant contribution it is removed from the equation. Finally the action stops when no variables in the equation can be removed and the next best candidate can not enter.

In this paper, the stepwise programme included in the BMDP statistical package were used (DIXON, 1981).

\section{Results}

Table 1 shows the correlations among variables considered in the equations. Because of the importance of low correlated predictive variables in finding good prediction equations it is suitable to note the not extremely high values of correlations regardless of correlation between carcass weight and slaughter weight.

\section{TABLE 1}

Correlations among traits.

Corrélations entre caractères.

\begin{tabular}{|c|c|c|c|c|c|c|c|c|c|}
\hline & SW & $\mathrm{CW}$ & $\mathrm{L}$ & LL & HLL & W & HLW & SL & $\mathrm{C}$ \\
\hline $\mathrm{SW}(\mathrm{g})$ & 1 & & & & & & & & \\
\hline CW (g) & .98 & 1 & & & & & & & \\
\hline$L(\mathrm{~cm})$ & .81 & .81 & 1 & & & & & & \\
\hline $\mathbf{L L}(\mathrm{cm})$ & .61 & .59 & .65 & 1 & & & & & \\
\hline HLL $(\mathrm{cm})$ & .47 & .45 & .57 & .22 & 1 & & & & \\
\hline$W(\mathrm{~cm})$ & .72 & .76 & .67 & .40 & .37 & 1 & & & \\
\hline HLW $(\mathrm{cm})$ & .40 & .39 & .37 & $-.02 \mathrm{NS}$ & .50 & .33 & 1 & & \\
\hline $\mathrm{SL}(\mathrm{cm})$ & .65 & .64 & .61 & .44 & .25 & .56 & .42 & 1 & \\
\hline $\mathrm{C}(\mathrm{cm})$ & .75 & .80 & .64 & .36 & .54 & .64 & .37 & .40 & 1 \\
\hline
\end{tabular}

Variable abreviations are in text - Les abréviations des variables se trouvent dans le texte. N.S. : not significant. The remaining correlations are significant at level 95 p. 100. N.S. : non significatif. Les corrélations restantes sont significatives au seuil de 95 p. 100.

Tables 2, 3 and 4 contain the coefficients of determination of carcass measurements, retail cuts weight and muscle group weights.

Slaughter weight and carcass weight are good predictors of total muscle of the carcass with coefficients of determination of 0.84 and 0.88 , respectively. Longitudinal 
TABLE 2

Means $(M)$, standard deviations $(S)$ and coefficients of determination $\left(R^{2}\right)$ of several traits on meat, bone, percent meat in the carcass and on meat to bone ratio.

Moyenne $(M)$, déviations typiques (S) et coefficients de détermination $\left(R^{2}\right)$ de plusieurs caractères sur la viande, l'os, le pourcentage de viande dans la carcasse, et le rapport muscle/os.

\begin{tabular}{|c|c|c|c|c|c|c|}
\hline & $\mathbf{M}$ & $S$ & $\mathbf{R}_{\mathrm{M}}^{2}$ & $\mathrm{R}_{\mathrm{M} / \mathrm{CW}}^{2}$ & $\mathrm{R}_{\mathrm{B}}^{2}$ & $\mathrm{R}_{\mathrm{M} / \mathrm{B}}^{2}$ \\
\hline SW (g) & 2094 & 247 & .84 & .02 & .64 & .08 \\
\hline$C W(g)$ & 1215 & 158 & .88 & .04 & .69 & .08 \\
\hline $\mathrm{L}(\mathrm{cm})$ & 32.6 & 1.2 & .63 & .08 & .43 & .10 \\
\hline LL $(\mathrm{cm})$ & 12.6 & .8 & .33 & .03 & .20 & .07 \\
\hline HLL (cm) & 19.3 & 1.2 & .27 & .15 & .07 & .17 \\
\hline $\mathrm{W}(\mathrm{cm})$ & 6.5 & .4 & .52 & .02 & .46 & .03 \\
\hline HLW $(\mathrm{cm})$ & 6.9 & .5 & .19 & .09 & .16 & .01 \\
\hline $\mathrm{SL}(\mathrm{cm})$ & 8.2 & .4 & .43 & .08 & .44 & .01 \\
\hline$C(\mathrm{~cm})$ & 16.5 & 1.0 & .67 & .12 & .41 & .13 \\
\hline $\mathrm{W} / \mathrm{L}$ & .20 & .01 & .02 & .00 & & \\
\hline $\mathrm{C} / \mathrm{L}$ & .51 & .02 & .16 & .03 & & \\
\hline M (g) & 642 & 95 & & & & \\
\hline $\mathrm{M} / \mathrm{CW}$ & .53 & .03 & & & & \\
\hline B (g) & 219 & 29 & & & & \\
\hline $\mathrm{M} / \mathrm{B}$ & 2.94 & .29 & & & & \\
\hline
\end{tabular}

Variable abreviations are in text - Les abréviations des variables se trouvent dans le texte.

TABLE 3

Means $(M)$, standard deviations $(S)$ and coefficients of determination $\left(R^{2}\right)$ of retail cuts.

Moyennes $(M)$, déviations typiques $(S)$ et coefficients de détermination $\left(R^{2}\right)$ des morceaux de découpe.

\begin{tabular}{|c|c|c|c|c|c|c|}
\hline & $\mathbf{M}$ & $S$ & $\mathbf{R}_{\mathrm{M}}^{2}$ & $\mathrm{R}_{\mathrm{M} / \mathrm{CW}}^{2}$ & $\mathbf{R}_{\mathrm{B}}^{2}$ & $\mathrm{R}_{\mathrm{M} / \mathrm{B}}^{2}$ \\
\hline FL $(g)$ & 127 & 20 & .71 & .13 & .65 & .03 \\
\hline HL (g) & 327 & 43 & .94 & .15 & .67 & .11 \\
\hline LO $(\mathrm{g})$ & 263 & 38 & .94 & .13 & .66 & .12 \\
\hline BR (g) & 158 & 24 & .77 & .07 & .67 & .04 \\
\hline$H(g)$ & 148 & 18 & .65 & .04 & .50 & .05 \\
\hline $\mathrm{LI}(\mathrm{g})$ & 74 & 14 & .15 & .01 & .12 & .01 \\
\hline KI (g) & 14.6 & 2.1 & .23 & .01 & .27 & .00 \\
\hline $\mathbf{H}+\mathbf{L}(\mathrm{g})$ & 27.7 & 6.0 & .20 & .00 & .07 & .08 \\
\hline
\end{tabular}

Variable abreviations are in text - Les abréviations des variables se trouvent dans le texte. 
TABLE 4

Means $(M)$, standard deviations $(S)$ and coefficients of determination $\left(R^{2}\right)$ of muscle groups.

Moyennes $(M)$, déviations typiques $(S)$, et coefficients de détermination $\left(R^{2}\right)$ des groupes de muscles.

\begin{tabular}{|c|c|c|c|c|}
\hline & $\mathbf{M}$ & $S$ & $\mathrm{R}_{\mathrm{M}}^{2}$ & $\mathbf{R}_{\mathrm{M} / \mathrm{CW}}^{2}$ \\
\hline MFL (g) & 48.6 & 8.6 & .67 & .20 \\
\hline MHL (g) & 131.0 & 19.3 & .97 & .23 \\
\hline MBR (g) & 37.4 & 10.2 & .38 & .18 \\
\hline Pl (g) & 22.3 & 4.0 & .78 & .21 \\
\hline P2 (g) & 10.7 & 2.2 & .55 & .07 \\
\hline $\mathrm{AW}(\mathrm{g})$ & 58.4 & 9.2 & .55 & .19 \\
\hline TLM (g) & 40.1 & 7.3 & .71 & .21 \\
\hline LLM (g) & $119.4^{-}$ & 21.5 & .88 & .17 \\
\hline LM (g) & 158.3 & 27.2 & .90 & .18 \\
\hline
\end{tabular}

Variable abreviations are in text - Les abréviations des variables se trouvent dans le texte.

measurements do not improve their capacity of prediction very much. Equation 1 (table 5) shows that only an improvement by about 3 p. 100 is reached by using these measurements together with carcass weight. Hind leg cut (HL) and hind leg muscle (MHL) yielded the best individual predictions (coefficients of determination of 0.94 and 0.97 , respectively).

Percent muscle in the carcass is not easy to predict. External measurements on carcass, retail cut weights and even muscle group weights were, separately, bad predictors of the muscle percentage of the carcass. The coefficients of determination ranged from 0.00 to 0.15 , from 0.00 to 0.15 and from 0.07 to 0.23 for external measurements, retail cuts and muscle groups respectively. Thus, hind leg muscle was the best predictor variable of percent muscle.

Predictions of bone weight and meat to bone ratio were also studied. Slaughter weight and carcass weight gave the best predictions of total bone weight, but worse than predictions of muscle weight (coefficients of determination of 0.64 and 0.69 respectively). Retail cut weights and external measurements do not provide good predictions of meat to bone ratio.

Table 5 gives the prediction equations of total muscle weight, carcass percent muscle, total bone weight, meat to bone ratio and some muscle groups using together external measurements, retail cut weights and muscle group weights as predictive variable measurements and derived according to the stepwise regression procedures.

Using 2 retail cut weights ( $\mathrm{HL}$ and $\mathrm{LO}$ ) and 3 external measurements (CW, HLL and SL) the prediction of total muscle weight arised a coefficient of determination of 0.98 (eq. 5, table 5). Identical coefficient was obtained by BocHNo et al. (1979) using measurements on chest, hind leg, and carcass weight from 40 rabbits. However, the residual standard deviation (RSD) was higher than the one in equation 5 ( 36.1 vs. 15.3). 


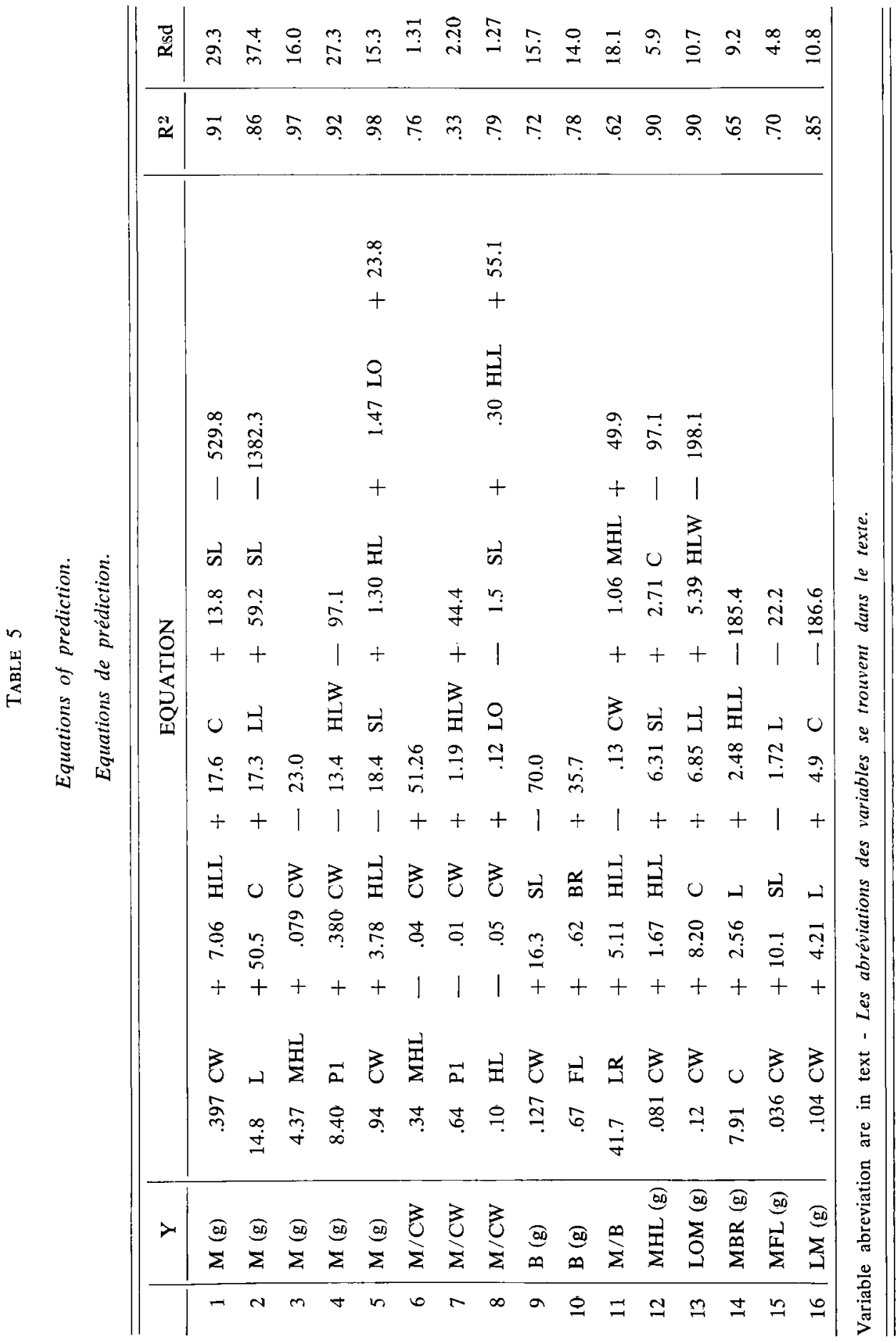


In contrast with total muscle weight, percent muscle and muscle to bone ratio achieved an important improvement of their predictions. Prediction of percent muscle in the carcass was improved notably using external measurements and sample retail cuts arising its coefficient of determination of 0.79 . However stepwise regression on percent muscle from external measurements only considered the first variable (HLL) whose coefficient of determination was 0.15 (Table 2). This fact had been observed formerly in other species (García de Siles et al., 1978, in cattle and pig.).

Muscle to bone ratio prediction was also improved including muscle to bone ratio on the hind leg in the equation (equation 11 . Table 5) with a resulting coefficient of determination of 0.62 .

Predictions on muscle weight in separate retail cuts and Longissimus muscle from external measurements on the carcass were made with a range of determination coefficients from 0.65 to 0.90 .

\section{Discussion}

Total carcass muscle weight was well predicted using only carcass weight or slaughter weight as a predictive variable and it was not therefore indispensable to use more difficult equations.

However, it was necessary to find solutions so as to improve the equations predicting the percent muscle in the carcass : measuring some traits independently, of carcass weight, using retail cut weights or some muscle region weights in the prediction.

Use of muscle groups in prediction was suggested by Rouvier (1970) using muscles of fore leg and CANTIER et al. (1974) using Infraspinatus. None of the muscle groups considered individually was a good predictor of percent muscle in the carcass although it is suitable to use them in the prediction of total muscle in the carcass (Table 4). A stepwise regression using carcass weight, external measurements and weight of some muscle groups as predictors of percent muscle in the carcass was made. The first two variables chosen were carcass weight and muscle mass weight of the hind leg; the resulting equation had a coefficient of determination of 0.76 (equation 6, Table 5). A stepwise regression with carcass weight, muscle mass weight on the hind leg and external measurements gave the same result. Psoas maior, easier to dissect than the hind leg muscle, was not a valuable predictor (equation 7 , Table 5).

When retail cut weights were used to predict percent muscle it was possible to make an acceptable equation. Even though stepwise regression from carcass weight, external measurements and retail cut weights as initial variables gave an equation of five predictors (CW, HL, SL, HLL, LO) whose coefficient of determination was 0.79 (equation 8 , Table 5), retail cut weights alone did not have sufficient predictive accuracy (Table 3).

The literature cited does not indicate any equation for prediction of percent muscle in rabbit carcass. In other species determination coefficient values obtained are generally quite low. EpLey et al. (1970) gave a maximum value of .76 for per- 
cent of trimmed retail cuts in cattle and SKELLEY et al. (1976) of 296 for percent of round, rump and loin cattle carcass. FATHEY et al. (1977) obtained a maximum value of .284 on percent corrected fat-free muscle.

The equations for prediction of bone weight (equations 9 and 10) had lower determination coefficients than those for prediction of muscle weight. Determination coefficients obtained by Bochno et al. (1979) and JANISzewsKa \& BochNo (1979) were similar to those in this work (.77 and .72 respectively). Muscle to bone ratio could only be determined from hind leg the ratio; even in that case the prediction was not very good.

\section{Conclusions}

Total carcass muscle mass was well predicted using carcass weight or slaughter weight as predictors in the regression equations ; their coefficients of determination were 0.88 and 0.84 , respectively. Nevertheless, percent in the carcass was more difficult to estimate even when external measurements, retail cuts, or dissected sample cuts were used individually. $\mathrm{R}^{2}$ of stepwise multiple regression on carcass percent muscle using external measurements carcass weight and sample retail cuts was 0.79 and when dissected sample cuts, carcass weight and external measurements were considered altogether as predictive variables the second regression step included the hind leg muscle and the carcass weight with a resulting $\mathrm{R}^{2}$ of 0.76 . Thus, it seems logic to use retail cuts as predictors of carcass percent muscle because it is not difficult to obtain retail cut weights and furthermore the carcass will not be devaluated.

Muscle to bone ratio on the carcass was predicted using muscle to bone ratio on the hind leg and other external measurements in the equation $\left(\mathrm{R}^{2}=0.62\right) . \mathrm{R}^{2}$ of other analyses were not high enough to be considered.

Muscle mass of some carcass regions can also be predicted using carcass external measurements and carcass weight with $R^{2}$ ranging from 0.65 to 0.90 .

\section{Résumé}

Prédiction de la quantité de viande et d'os du lapin avec mesures sur la carcasse et morceaux de découpe

Des équations de régression pour prédire le poids de la viande comestible du lapin, à partir des mesures effectuées sur la carcasse sont présentées; on prédit aussi la quantité d'os et de muscle.

Les équations présentent des coefficients de détermination élevés; l'équation de prédiction de la viande comestible a un $\mathrm{R}^{2}=0.91$, et celle permettant de prédire le pourcentage de viande dans la carcasse un $R^{2}=0.79$.

Pour obtenir de bonnes équations de prédiction du pourcentage de viande de la carcasse, il est nécessaire d'inclure les mesures de découpe.

On présente des équations de prédiction du rapport viande/os, qui utilisent des mesures externes et les renseignements sur la dissection d'une cuisse. 
On étudie la capacité individuelle de certaines mesures externes, de diverses parties de découpe et des masses musculaires pour prédire la quantité totale de viande de la carcasse, le pourcentage de viande, le poids total des os et le rapport viande/os.

Mots clés : lapin, viande, carcasse, os, muscles, correlations.

Received in March 1983.

Accepted in January 1984.

\section{References}

BaSelga M., 1978. Análisis genético de diversas caractérísticas de crecimiento en el conejo de producción de carne. In : $3^{\text {er }}$ Symposium Canicultura, 9-10 Noviembre, AsEscu, 111-126.

Bochno R., LewCZuK A., JANISZEWSKa M., 1979. Analiza prozidtnossi niecktarich cech przyciowich; poubojowych de oceny wartosci rzezenj turzsek Koólicazich. Rcz. Nauk Zoot., T. 6, z. 1, 175-183.

Cantier J., Vezinhet A., Rouvier R., Dauzier L., 1969. Allométrie de croissance chez le lapin. I. Principaux organes et tissus. Ann. Biol. Anim. Biochim. Biophys., 9, 5-39.

Cantier J., Vezinhet A., Dulor J.P., Rouvier R., 1974. Allométrie de croissance chez le lapin. IV. Principaux muscles de la carcasse. Ann. Biol. Anim. Biochim. Biophys., 16, 569-577.

DrXoN W.J. (Ed.), 1981. BMDP. University of California Press. Berkeley.

Drapper N., SMITH H., 1981. Applied regression analysis. John Wiley \& sons.

Epley R., Hedrich H.B., Stringer N.C., Hutcheson D.P., 1970. Prediction of weight and percent retail cuts of beef using five carcass measurements. J. Anim. Sci., 30, 872-879.

Fahey I., Schaefer D.H., Kauffman R.G., Epley R.J., Gould P.F., Romans J.R., Smith J.C., TOPEL D.G., 1977. A comparison of practical methods to estimate pork carcass composition. J. Anim. Sci., 44, 8-17.

Garcia de Siles J.L., Martinez J.L., Galvez J.F., 1978. Relación entre las medidas lineales de las canales vacuna y porcina y sus rendimientos al despiece. Anales INIA. Ser. Prod. Anim., 9, 147-153.

JANISZEwSKa M., Bochno R., 1979. Prydatność niektórich cechprzyzicio wych; poubojowch do oceany umieśnienia tuszek Króliczych. Zesz. Nauk. ART. Zoot., 19, 119-128.

Rouvier R., 1970. Variabilité génétique du rendement a l'abattage et de la composition anatomique de lapins de trois races. Ann. Génét. Sél. Anim., 213, 325-346.

Skelley G.C., Durfos D.A., BonetTe J.E., J.R. 1972. The relationships between certain bone measurements and cutability of beef carcass. J. Anim. Sci., 35, 518-524.

VarewYCK H., Bouguet Y., 1982. Relations entre la composition tissulaire de la carcasse de lapins de boucherie et celle des principaux morceaux. Ann. Zootech., 31, 257-268. 